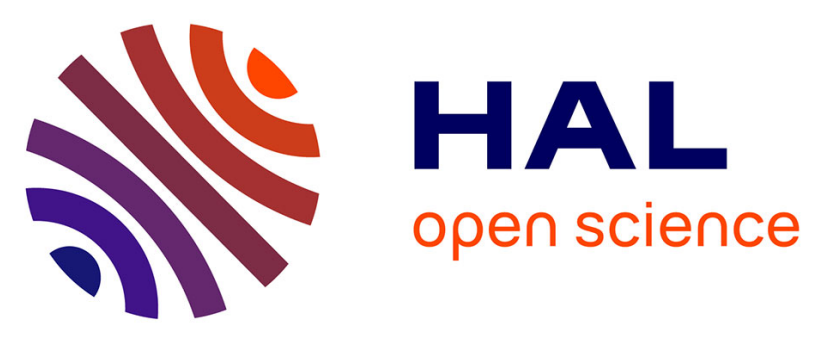

\title{
Effects of progressive hypoxia on oxygen uptake in juveniles of the Peruvian scallop, Argopecten purpuratus (Lamarck, 1819)
}

Arturo Aguirre-Velarde, Fred Jean, Gérard Thouzeau, Jonathan Flye-Sainte-Marie

\section{To cite this version:}

Arturo Aguirre-Velarde, Fred Jean, Gérard Thouzeau, Jonathan Flye-Sainte-Marie. Effects of progressive hypoxia on oxygen uptake in juveniles of the Peruvian scallop, Argopecten purpuratus (Lamarck, 1819). Aquaculture, 2016, 451, pp.385-389. 10.1016/j.aquaculture.2015.07.030 . hal-01282771

\section{HAL Id: hal-01282771 \\ https://hal.univ-brest.fr/hal-01282771}

Submitted on 4 Mar 2016

HAL is a multi-disciplinary open access archive for the deposit and dissemination of scientific research documents, whether they are published or not. The documents may come from teaching and research institutions in France or abroad, or from public or private research centers.
L'archive ouverte pluridisciplinaire HAL, est destinée au dépôt et à la diffusion de documents scientifiques de niveau recherche, publiés ou non, émanant des établissements d'enseignement et de recherche français ou étrangers, des laboratoires publics ou privés. 


\title{
Effects of progressive hypoxia on oxygen uptake in juveniles of the Peruvian scallop, Argopecten purpuratus (Lamarck, 1819)
}

\author{
Arturo Aguirre-Velarde ${ }^{\mathrm{a}, \mathrm{b}}$, Fred Jean ${ }^{\mathrm{a}}$, Gérard Thouzeau ${ }^{\mathrm{a}}$, Jonathan Flye-Sainte-Marie ${ }^{\mathrm{a}, *}$ \\ ${ }^{a}$ LEMAR, UMR 6539 (UBO/CNRS/IRD/Ifremer), IUEM, Rue Dumont d'Urville, 29280 Plouzané, France \\ ${ }^{b}$ Laboratorio de Ecofisiología Acuática, Instituto del Mar del Perú(IMARPE), Esquina Gamarra y General Valle S/N Chucuito Callao, Peru
}

\begin{abstract}
A field survey performed in Paracas Bay (Peru), a major scallop culture area, showed that the Peruvian scallop, Argopecten purpuratus, periodically faces severe hypoxic events. Oxygen uptake rate $\left(\mathrm{VO}_{2}\right)$ of A. purpuratus juveniles facing progressive decrease of environmental oxygen saturation (from $100 \%$ to $5 \%$ ) was measured at two contrasting temperatures ("normal condition" $=16^{\circ} \mathrm{C}$ and "warm condition" $=25^{\circ} \mathrm{C}$ ). In normoxia, (oxygen saturation $\left.>70 \%\right)$ average $V O_{2}$ was significantly $(p<0.001)$ higher in warm condition $\left(0.20 \pm 0.004 \mathrm{mgO}_{2}\right.$ ind $\left.^{-1} \mathrm{~h}^{-1}\right)$ than in normal condition $\left(0.12 \pm 0.007 \mathrm{mgO}_{2}\right.$ ind $\left.^{-1} \mathrm{~h}^{-1}\right)$. The shape of the $V O_{2}$ response curve during increasing hypoxic conditions was evaluated using a segmented linear regression. The break points between linear segments allowed estimating the oxygen critical points $\left(\mathrm{P}_{\mathrm{c}} \mathrm{O}_{2}\right.$, oxygen saturation units), while the slopes of the various segments was used to assess the $V O_{2}$ regulatory capacity. In both temperature conditions at oxygen saturation lower than $\mathrm{P}_{\mathrm{c}} \mathrm{O}_{2}, V O_{2}$ was a fourth of the values recorded in normoxic condition. This trend was more pronounced in the warm condition. Paradoxically, the estimated $\mathrm{P}_{\mathrm{c}} \mathrm{O}_{2}$ was lower in warm condition $(21.4 \% \pm 0.7)$ compared to the normal condition $(24.4 \% \pm 1.9)$. However, the study of the slopes at oxygen saturations higher than $\mathrm{P}_{\mathrm{c}} \mathrm{O}_{2}$ revealed that $A$. purpuratus can regulate its respiratory rate similarly and efficiently at both 16 and $25^{\circ} \mathrm{C}$. Moreover, for $V O_{2}$ above $\mathrm{P}_{\mathrm{c}} \mathrm{O}_{2}$, the estimated $Q_{10}$ between normal and warm conditions was 1.78 (Arrhenius temperature $=4983 \mathrm{~K}$ ), highlighting a moderate effect of temperature on $\mathrm{VO}_{2}$. These results reflect the adaptive capacity of this species to the changing environment along the Peruvian-Chilean coasts influenced by upwelling system and ENSO events. However, results from this study indicate that, at least during some periods, A. purpuratus spend more than $70 \%$ of its time exposed to hypoxic conditions below the estimated $\mathrm{P}_{\mathrm{c}} \mathrm{O}_{2}$. Such conditions could have negative consequences on the species metabolism and harm the performance of A. purpuratus culture.
\end{abstract}

Keywords:

Argopecten purpuratus, Oxygen critical point, Oxyregulation, Respiration, Aquaculture, Peru

\section{Introduction}

Peruvian coastal waters are characterized by an intense upwelling system. The associated high primary production supports a large biomass of filter feeders (Thiel, 1978). Among those, the Peruvian scallop, Argopecten purpuratus, is a major species for Peruvian aquaculture. In 2012, aquaculture production in Peru reached more than 67000 tons and a value of about 159 million USD (PRODUCE - Peru, 2015).

Massive mortality events, that affected production and subsequently local economy (Cabello et al., 2002; González-Hunt, 2010; Gonzales et al., 2012), have been repeatedly observed in coastal bays. Environmental monitoring (e.g. dissolved oxygen, temperature and toxic blooms surveys) is scarce in coastal areas in Peru.

Aquatic organisms can be characterized by their ability to regulate their oxygen uptake when exposed to moderate and/or severe hypoxia (Le Moullac et al., 2007). Species exhibiting an oxygen uptake dependent on environmental oxygen concentration are called "oxyconformers". In contrast, those who are able

*Email: jonathan.flye@univ-brest.fr to maintain their oxygen uptake independently of the external decrease in oxygen concentration, at least for a part of the oxygen decrease range, can be classified as "oxyregulators". Nevertheless, Mangum and Winkle (1973) stressed that this classification is no more than the two extreme ends of a range of gradual physiological responses. The oxygen critical point $\left(\mathrm{P}_{\mathrm{c}} \mathrm{O}_{2}\right)$ concept was introduced by Prosser (1973) to characterize the oxygen level below which an oxyregulator cannot keep its oxygen uptake independent of external concentration. The $\mathrm{P}_{c} \mathrm{O}_{2}$ would coincide with the initiation of anaerobic metabolic pathways (Herreid, 1980; Pörtner and Grieshaber, 1993). Switching from aerobic to anaerobic energy production leads to a lower ATP yield per unit glucose and generates accumulation of endproducts which might be metabolized when normoxic conditions resume. This phenomenon has been described as the oxygen debt (Herreid, 1980). Because metabolic pathways are affected by hypoxia, it can be hypothesized that energetics and subsequently growth and reproduction can also be affected.

Temperature also affects oxygen uptake regulation in marine bivalves by modifying $\mathrm{P}_{\mathrm{c}} \mathrm{O}_{2}$ and/or shape of respiratory response against progressive hypoxia (e.g. Le Moullac et al., 2007; Artigaud et al., 2014). In scallops bed of the Peruvian 
coast, water temperature variations up to $8^{\circ} \mathrm{C}$ in a few hours can be observed presumably due to variation in the intensity of the adjacent upwelling system (Aguirre-Velarde et al., 2014). In addition, Peruvian-Chilean coastal waters frequently experience important temperature variations due to El Niño Southern Oscillation (ENSO). The latter can induce dramatic increases of water temperature (about $10^{\circ} \mathrm{C}$ ) (Wolff, 1987, 1988; Cantillánez et al., 2007; Avendaño et al., 2008).

In order to better understand how physiology and energetics of $A$. purpuratus are affected by these fluctuating environmental conditions, this study was designed to focus on the metabolic response of this species to temperature and oxygen concentration. In this context, the present study aims at characterizing the respiratory response of $A$. purpuratus under progressive exposition to hypoxia at two contrasted temperatures (warm condition vs normal condition). A field survey was also performed in early 2013 in Paracas Bay, wich is a main scallop culture area in Peru, to characterize the duration and magnitude of scallop exposure to hypoxic conditions.

\section{Material and methods}

\subsection{Field monitoring}

Field measurements of temperature and dissolved oxygen saturation of the near-bottom water $(20 \mathrm{~cm}$ above the bottom) were performed in an A. purpuratus aquaculture bed located in in Paracas Bay (Peru; 13 ${ }^{\circ} 49^{\prime} 35^{\prime \prime} \mathrm{S}, 7^{\circ} 17^{\prime} 43^{\prime \prime} \mathrm{W}$ ) using autonomous dataloggers (HOBO U22-001 and RBR TDO for temperature and oxygen, respectively) from January $1^{\text {st }}$, to March $10,2013$.

\subsection{Laboratory experiment}

Scallops ranging from 24 to $32 \mathrm{~mm}$ in shell height were provided by La Arena hatchery (FONDEPES, Casma, Peru) and transfered to the Laboratorio de Investigaciones Acuícola of IMARPE (Callao, Peru) on the 27 of July 2013. After transfer to the laboratory, the scallops were acclimated into two thermoregulated 200-L tanks during 2 days with a constant $1 \mu \mathrm{m}-$ filtered seawater flow $\left(8 \mathrm{Lh}^{-1}\right)$. No food was given during the whole experiment because (1) feeding rate is generally dependent on temperature and affects respiration rate and (2) the present experiment was performed over a short time period. One tank was maintained at $16^{\circ} \mathrm{C}$ ("normal condition") while the other one was progressively heated up to $25^{\circ} \mathrm{C}$ ("warm condition") in four days. Afterwards, the temperature was maintained constant.

Oxygen uptake measurements were performed in a third tank thermoregulated at the acclimation temperature (16 or 25 $\left.{ }^{\circ} \mathrm{C}\right)$. Temperature recordings within the tanks (15-min intervals) showed that water thermoregulation for respiration measurements was accurate and stable. In the normal condition, the average temperature during the whole experiment was $16.0^{\circ} \mathrm{C}$ $\left(\max .=16.2^{\circ} \mathrm{C}, \min .=15.9^{\circ} \mathrm{C}\right)$. In the warm condition, the average temperature during the experiment was $25.2^{\circ} \mathrm{C}(\max .=$ $25.4^{\circ} \mathrm{C}$, min. $=24.9^{\circ} \mathrm{C}$ ). The experimental setting used was extensively described in Artigaud et al. (2014). Briefly, a computercontrolled system allowed to gradually decrease the concentration of oxygen within the experimental tank by the mean of injection of gaseous nitrogen $\left(\mathrm{N}_{2}\right)$ in the water. Gas exchanges with the atmosphere were limited by the mean of a floating PVC sheet placed on the water surface. The system allowed decreasing the dissolved oxygen percent saturation stepwise from $100 \%$ to $5 \%$ by steps of $10 \%$ to $5 \%$ every $2 \mathrm{~h}$. During the whole sequence of decrease of oxygen saturation, oxygen uptake rate by scallops was measured by repeated incubations in $0.59-\mathrm{L}$ acrylic chambers. Six chambers were used in total, 5 chambers contained each four individuals, while the sixth one was used as a control and contained four empty scallop valves (which the external surface approximately equals the external surface of four individuals). Each incubation lasted $20 \mathrm{~min}$; between two incubations, water within the chambers was automatically renewed by pumping water from the experimental tank for 5 min. At the end of each experimentation, scallop height and total volume were measured in each chamber.

For each temperature condition, the experimentation was repeated four times leading to a total of twenty replicates for each treatment. Between each experimentation, chambers were washed with a diluted hydrogen peroxide solution.

The individual oxygen uptake rate $\left(\mathrm{VO}_{2}, \mathrm{mgO}_{2}\right.$ ind $\left.^{-1} \mathrm{~h}^{-1}\right)$, was calculated as:

$$
V \mathrm{O}_{2}=\frac{\mathrm{O}_{2} C R_{\text {chamb }}-\mathrm{O}_{2} C R_{\text {cont }}}{n_{\text {ind }}}
$$

with:

$\mathrm{O}_{2} \mathrm{CR}_{\text {chamb }}$ : the oxygen consumption rate in chamber with scallops $\left(\mathrm{mg} \mathrm{O}_{2} \mathrm{~L}^{-1} \mathrm{~h}^{-1}\right)$

$\mathrm{O}_{2} C R_{\text {cont }}$ : the oxygen consumption rate in control chamber $\left(\mathrm{mgO}_{2} \mathrm{~L}^{-1} \mathrm{~h}^{-1}\right)$

$n_{\text {ind }}:$ the number of individuals into the chamber

Given the possible difference in scallop mean size between the chambers, estimated oxygen uptake rates were standardized to a 30-mm height individual using Bayne et al. (1987) formula:

$$
V O_{2 s t d}=V O_{2} \cdot\left(\frac{H_{s t d}}{H_{\text {mean }}}\right)^{b}
$$

with:

$V O_{2 s t d}$ : oxygen uptake $\left(\mathrm{mgO}_{2}\right.$ ind $\left.^{-1} \mathrm{~h}^{-1}\right)$ standardized for an arbitrary height $H_{s t d}$ ( fixed to $30 \mathrm{~mm}$ )

$V O_{2}$ : measured individual oxygen uptake into the chamber $\left(\mathrm{mgO}_{2}\right.$ ind $\left.^{-1} \mathrm{~h}^{-1}\right)$

$H_{\text {mean }}$ : mean scallops height into the chamber (mm)

$b$ : allometric relationship between size and oxygen uptake. In the review of Savina and Pouvreau (2004), the allometric coefficient that relates respiration rate to weight is close to $3 / 4$ in bivalves. This coefficient was recalculated to 2.25 in this study in order to relate respiration rate to height (or length) based on the assumption that weight scales with cubic length (or height). 
The oxygen critical point (abrupt decrease in respiration rate or break point) was calculated using a segmented linear regression method (Muggeo, 2003), as proposed by Artigaud et al. (2014), from measurements of oxygen uptake vs oxygen saturation. The capacity of oxygen uptake regulation under progressive hypoxia was evaluated through the $" \mathrm{O}_{2}$ regulation percentage" of Hicks and McMahon (2002). This value corresponds to the ratio between (1) the area beneath the curve of oxygen uptake versus oxygen saturation (expressed as percentage of maximum oxygen uptake i.e saturation $=100 \%$ ) and (2) the area achieved by a perfect oxyregulator (displaying a constant respiration rate whatever the level of oxygen saturation). All computations were performed using $\mathrm{R}$ software ( $\mathrm{R}$ Development Core Team, 2011); segmented linear regressions were performed using the "segmented" R package (Muggeo, 2008).

The effect of temperature on A. purpuratus oxygen uptake was assessed through the $Q_{10}$ temperature coefficient calculated as : $Q_{10}=\left(\dot{k}_{1} / \dot{k}_{2}\right)^{10 /\left(T_{2}-T_{1}\right)}$, where $\dot{k}_{1}$ is the metabolic rate measured at temperature $T_{1}, \dot{k}_{2}$ is the metabolic rate measured at temperature $T_{2}$, and $T_{1}<T_{2}$ using respiration rates in normoxia ( $V \mathrm{O}_{2 s t d}$ for oxygen saturation above $70 \%$ ). The Arrhenius temperature $\left(T_{A}, \mathrm{~K}\right)$ is frequently used to assess the effect of temperature on physiological rates in bioenergetic models within the thermal range tolerance of a species (Kooijman, 2010). This parameter was estimated from $Q_{10}$ using the relationship proposed by Kooijman (2010): $T_{A}=\left[\ln Q_{10} \cdot T \cdot(T+10)\right] / 10$, with $T$ the reference temperature (i.e. $289 \mathrm{~K}$ )

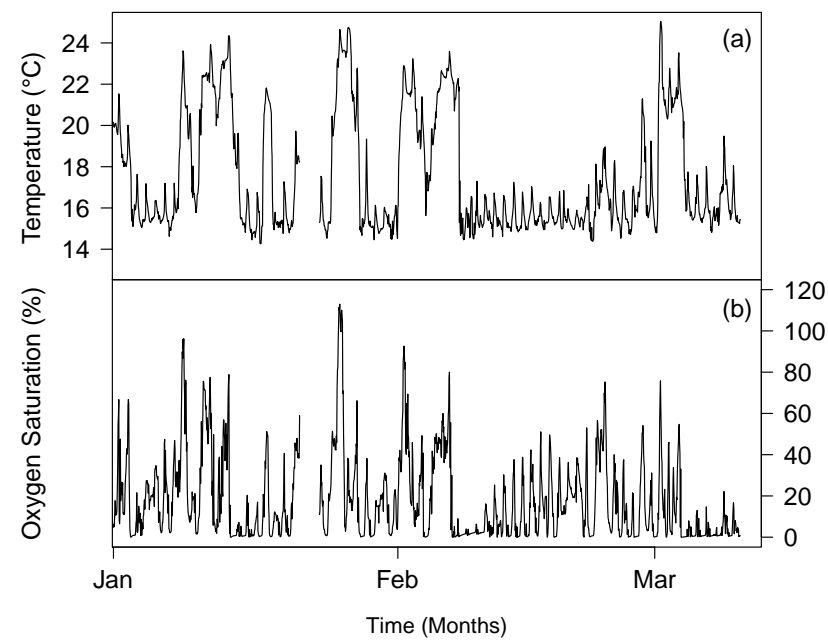

Figure 1: Temperature and oxygen saturation of near-bottom water $(20 \mathrm{~cm}$ above the bottom) of an A. purpuratus aquaculture bed located in Paracas Bay (Peru, 13⒋ $49^{\prime} 35^{\prime} \mathrm{S}, 76^{\circ} 17^{\prime} 43^{\prime \prime} \mathrm{W}$ ) measured between the January $1^{\text {st }}$, and the March 10, 2013.

\section{Results}

During the monitoring period, the oxygen saturation of the near bottom water varied from $0 \%$ to $112 \%$ (Fig. 1) and the average saturation was $18 \%$. During the 69 days of monitoring, the aquaculture bed faced under saturation below $24 \%$ for $70 \%$

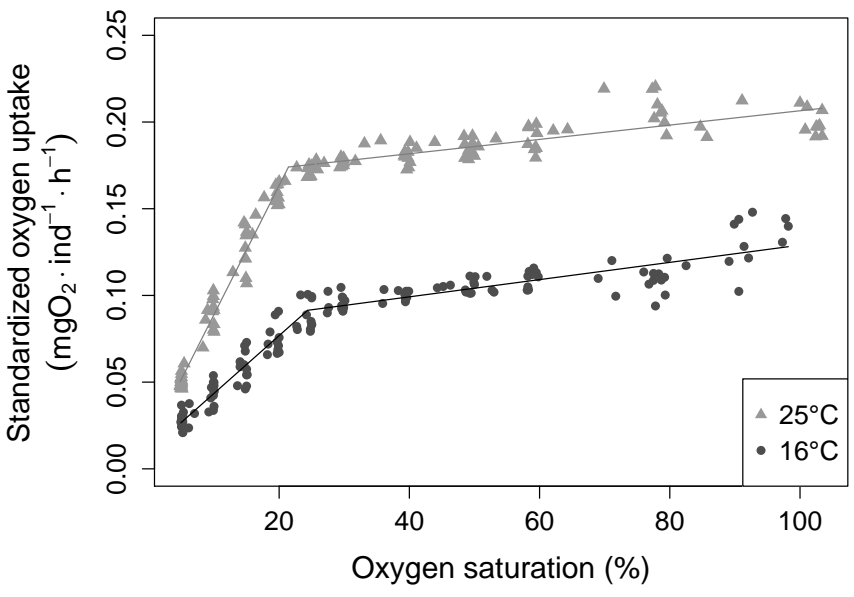

Figure 2: Standardized ( $30 \mathrm{~mm}$ shell height) individual oxygen uptake rate of Argopecten purpuratus facing progressive hypoxia at 16 and $25^{\circ} \mathrm{C}$. Lines are the segmented linear models used to calculate the critical oxygen point at both temperatures. Estimated break points $\left(\mathrm{P}_{\mathrm{c}} \mathrm{O}_{2}\right)$ were $24.4 \%(\mathrm{CI}=1.9)$ at $16^{\circ} \mathrm{C}$ and $21.4 \%(\mathrm{CI}=0.7)$ at $25^{\circ} \mathrm{C}$. No significant difference in the slopes of the linear segments above $\mathrm{P}_{c} \mathrm{O}_{2}$ was found between the two treatments, whereas slopes were significantly different for oxygen saturation below $\mathrm{P}_{\mathrm{c}} \mathrm{O}_{2}$.

of the time. Temperature varied between $14.2^{\circ} \mathrm{C}$ and $23.7^{\circ} \mathrm{C}$ and average was $16.3^{\circ} \mathrm{C}$. Dramatic daily temperature changes were frequently observed: on March $1^{\text {st }} 2013$ the temperature varied from $14.7^{\circ} \mathrm{C}$ to $22.9^{\circ} \mathrm{C}$ (increase of $8.2^{\circ} \mathrm{C}$ ) within a few hours.

Measured standardized oxygen uptake rate in normoxic conditions $\left(\mathrm{O}_{2}\right.$ saturation $\left.>70 \%\right)$ was $0.12 \pm 0.007 \mathrm{mgO}_{2}$ ind $^{-1} \mathrm{~h}^{-1}$ at $16^{\circ} \mathrm{C}$ and $0.20 \pm 0.004 \mathrm{mgO}_{2}$ ind $^{-1} \mathrm{~h}^{-1}$ at $25^{\circ} \mathrm{C}$. Those data allowed to estimate the $Q_{10}$ to 1.78 and the corresponding value of $T_{A}$ was $4983 \mathrm{~K}$. Under severe hypoxia $\left(\mathrm{O}_{2}\right.$ saturation close to $5.5 \%), V O_{2 s t d}$ was $0.027 \pm 0.002 \mathrm{mgO}_{2}$ ind $^{-1} \mathrm{~h}^{-1}$ at $16^{\circ} \mathrm{C}$ and $0.050 \pm 0.002$ at $25^{\circ} \mathrm{C}$, that is $22.5 \%$ and $25 \%$ of the values measured in normoxic conditions, respectively. In both normoxic and severe hypoxic conditions, $V O_{2 s t d}$ was significantly higher in warm than in normal condition $(p<0.001$, Kruskal Wallis test).

The results of the segmented linear regression models fitted on the oxygen uptake rates as a function of oxygen saturation indicate a $\mathrm{P}_{\mathrm{c}} \mathrm{O}_{2}$ (break point) at $24.4 \% \pm 1.9$ in normal condition $\left(16^{\circ} \mathrm{C}\right)$ and at $21.4 \% \pm 0.7$ in warm condition $\left(25^{\circ} \mathrm{C}\right)$ (Fig. 2 , tab. 1). In both conditions, a strong decrease of oxygen uptake rate is observed when oxygen saturation drops below the $\mathrm{P}_{\mathrm{c}} \mathrm{O}_{2}$ (break point), segmented linear regressions indicating significant changes in the slopes of linear segments (Davies' test, $p<0.001)$. Likewise in both experimental temperature conditions, the regression slopes show that both $\mathrm{P}_{\mathrm{c}} \mathrm{O}_{2}$ lower and higher segments depend significantly $(p<0.001)$ on oxygen saturation although in a different extent.

Comparison of the slopes of the segments above and below the $\mathrm{P}_{\mathrm{c}} \mathrm{O}_{2}$ was assessed through analysis of covariance (ANCOVA); it allowed comparing the respiratory response of the scallops to progressive hypoxia between two temperature expo- 
Table 1: Oxygen critical points values $\left(\mathrm{P}_{\mathrm{c}} \mathrm{O}_{2}\right)$ and percentage of regulation estimated for Argopecten purpuratus at 16 and $25^{\circ} \mathrm{C}$ using segmented linear regression. The table indicates the slopes and confidence intervals of the linear segments below and above the break points $\left(\mathrm{P}_{\mathrm{c}} \mathrm{O}_{2}\right)$.

\begin{tabular}{lcccc}
\hline $\begin{array}{l}\text { Temperature } \\
\left({ }^{\circ} \mathrm{C}\right)\end{array}$ & $\mathrm{P}_{\mathrm{c}} \mathrm{O}_{2}$ & \multicolumn{2}{c}{ Linear segment slopes } & \% Regulation \\
\hline 16 & $(\% \pm \mathrm{CI})$ & Segment $<\mathrm{P}_{\mathrm{c}} \mathrm{O}_{2}$ & Segment $>\mathrm{P}_{\mathrm{c}} \mathrm{O}_{2}$ & $(\%)$ \\
25 & $24.4 \pm 1.9$ & $3.3410^{-3} \pm 3.310^{-4}$ & $4.9710^{-3} \pm 7.610^{-5}$ & 74 \\
\hline
\end{tabular}

sures. The comparison of the segments superior to $\mathrm{P}_{c} \mathrm{O}_{2}$ shows no significant interaction $(p>0.05)$ between temperature and oxygen saturation on oxygen uptake indicating no significant difference for slopes between the two temperature conditions. Thus for saturations above $\mathrm{P}_{c} \mathrm{O}_{2}$, regulation of oxygen uptake in function of oxygen availability is identical. For saturations below $\mathrm{P}_{\mathrm{c}} \mathrm{O}_{2}$, interaction between temperature and oxygen saturation was significant $(p<0.001)$ indicating that the slopes are significantly different between treatments. Therefore, below $\mathrm{P}_{\mathrm{c}} \mathrm{O}_{2}$, the oxygen uptake regulation depends on oxygen saturation but also on temperature. At $25^{\circ} \mathrm{C}$, respiration rate decrease is 2.2 -fold higher than at $16^{\circ} \mathrm{C}$ when saturation falls below $\mathrm{P}_{\mathrm{c}} \mathrm{O}_{2}$. Finally, regulation capacity was slightly higher at $25^{\circ} \mathrm{C}(82 \%)$ than at $16^{\circ} \mathrm{C}(74 \%$; see Table 1$)$.

\section{Discussion}

Traditional dichotomy between "oxyconformers" and "oxyregulators" has been criticized because of the varied responses of organisms facing progressive decrease of environmental oxygen saturation (Mangum and Winkle, 1973; Taylor and Brand, 1975). Herreid (1980) considers that "good regulators" have low $\mathrm{P}_{\mathrm{c}} \mathrm{O}_{2}$ values and abrupt transitions and steep conformity slopes. "Poor regulators" are expected to have a more gradual transition from regulation to conformity. Bivalves species inhabiting periodically hypoxic habitats, are generally found to be better regulators when submitted to progressive hypoxia (Griffiths and Griffiths, 1987). This is the case in Peruvian coastal bays where the environmental monitoring presented in this study showed that $A$. purpuratus is frequently exposed to severe hypoxic conditions. The effects of environmental hypoxic events on marine natural (Llanso, 1992) or cultured (Brokordt et al., 2013) populations depend on the intensity and duration of these events. Brokordt et al. (2013) found that hypoxia exposition affects the escape capacity of $A$. purpuratus increasing vulnerability to predation and decreasing physiological capabilities to support other stress factors. To maintain oxygen uptake when oxygen availability decreases, bivalves can respond by increasing water pumping/ventilation (Tran et al., 2000) and cardiac activities (Grieshaber et al., 1994). This set of responses can be considered as a "oxyregulation effort", where $\mathrm{P}_{\mathrm{c}} \mathrm{O}_{2}$ represents the limit of regulatory ability (Grieshaber et al., 1988). Although oxygen uptake is not completely independent of oxygen saturation for oxygen saturations higher than $\mathrm{P}_{\mathrm{c}} \mathrm{O}_{2}$ ("regulated segment"), A. purpuratus exhibits relatively low $\mathrm{P}_{\mathrm{c}} \mathrm{O}_{2}$ (Fig. 2) and can thus be considered as a good regulator. Recently, Artigaud et al. (2014) estimated a similar $\mathrm{P}_{\mathrm{c}} \mathrm{O}_{2}$ value $\left(23.8 \%\right.$ at $\left.18^{\circ} \mathrm{C}\right)$ for Pecten maximus which is phylogenetically closely related. It can thus be hypothesized that morphology/anatomy plays a role in the physical oxyregulation ability (e.g. ventilation, oxygen perfusion). Nevertheless, results of Artigaud et al. (2014) indicate that in P. maximus, which is less naturally exposed to abrupt changes in temperature, regulation ability is more sensitive to temperature.

Generally, $\mathrm{P}_{\mathrm{c}} \mathrm{O}_{2}$ increases with temperature (Herreid, 1980), this relationship resting upon the temperature-dependence of oxygen solubility in seawater (Le Moullac et al., 2007). Interestingly, the difference of estimated $\mathrm{P}_{\mathrm{c}} \mathrm{O}_{2}$ was very low between both temperature exposures in this study, and was associated with a regulation ability slightly higher at $25^{\circ} \mathrm{C}$ than at $16^{\circ} \mathrm{C}$. This pattern might be associated with an increased metabolic capacity for ciliary ventilation and/or hemolymph perfusion of the gills (Alexander and McMahon, 2004). This can explain also the significantly higher oxygen uptake in warm conditions under severe hypoxia $\left(\mathrm{O}_{2}\right.$ saturation near $\left.5.5 \%\right)$ compared to normal $\left(16^{\circ} \mathrm{C}\right)$ condition. Such a positive relationship between temperature and oxygen uptake regulation has also been found in the fresh water bivalves Sphaerium simile (Waite and Neufeld, 1977) and Dreissena polymorpha (Alexander and McMahon, 2004). On the other hand, in upwelling zones, as along the Peruvian coast, hypoxia can occur at low temperatures. Under low temperature conditions, the reduced efficiency of regulation strategies may cause a early decrease of oxyregulation effort and consequently of oxygen uptake rate. Increased metabolic rate (higher energetic demand) at elevated temperatures may need extending oxyregulation effort to maintain aerobic metabolism. Indeed, the latter is more efficient in terms of ATP production.

Respiration rates generally increase with body temperature until a threshold temperature is reached (Hand and Hardewig, 1996). The $Q_{10}$ value of 1.78 calculated from oxygen uptake data in normoxia is close to values characteristic of temperaturedependent physiological response $\left(Q_{10}\right.$ ranging between 2 and 3; Willmer et al., 2005). This $Q_{10}$ value is slightly lower than the lower limit of this range, which reflects a moderate effect of temperature on physiological rate. The latter may favor the maintenance of homeostasis in an environment presenting high temperature fluctuations. Comparisons of subtidal (relatively stable temperature) and intertidal (highly fluctuating temperature) mollusk species show that species experiencing high temperature fluctuations (intertidal) present lower $Q_{10}$ (e.g. Sokolova and Pörtner, 2003; Dunphy et al., 2006). A. 
purpuratus displays a ability to adapt/acclimate to both high temperature, i.e. during El Niño events $\left(\approx 24^{\circ} \mathrm{C}\right.$ in Peru, Wolff, $1987)$, and low temperatures $\left(\approx 12^{\circ} \mathrm{C}\right.$ in Southern Chile, Gonzalez et al., $2002 ; 13-14^{\circ} \mathrm{C}$ in Northern Chile during la Niña events, Cantillánez et al., 2007). In addition, similarly to intertidal species, temperature changes higher than $8^{\circ} \mathrm{C}$, combined with dramatic changes in oxygen concentration, were recorded in few hours in Paracas Bay, Peru. Wolff (1987) suggested that A. purpuratus was a relict form of the subtropical fauna which once inhabited Chile and Peru during Miocene. Adaptations to warm conditions, including hypoxia handling, may have preserved after the general cooling of the oceans at the end of the Miocene due to periodical El Niño occurrence on the Peruvian coastal zones. This relative low effect of temperature on physiological rates combined with a good regulation of oxygen uptake under hypoxia might explain the ability of this species to adapt/acclimate to such conditions. In an environment where trophic resource is poorly limiting, A. purpuratus is well adapted to cope with temperature changes and to deal with frequent hypoxia events under both cold and warm conditions. Such a strategy would allow maintaining aerobic metabolic pathways and efficiently using food resources (e.g. for growth and reproduction) under low oxygen concentration. The success of A. purpuratus aquaculture can be related to its ability to acclimate to this very dynamic environment, while displaying important growth rates in comparison to other scallops species. It is clear from this study however that $A$. purpuratus aquaculture could be optimized by selecting culture areas (bottom and suspended cultures) presenting the best fit between temperature and oxygen fluctuations, and metabolic rates.

Several studies showed that temperature strongly impacts the organisms ability to cope with hypoxia (Newell, 1978; McMahon and Wilson, 1981; Hicks and McMahon, 2002; Jansen et al., 2009; Alexander and McMahon, 2004; Le Moullac et al., 2007; Pörtner, 2012; Artigaud et al., 2014). Artigaud et al. (2014) found an inverse relationship between the temperature and percentage of regulation in $P$. maximus, while Hicks and McMahon (2002) found a direct relationship in Perna perna. In the present study, the calculated percentage of regulation was slightly greater at $25^{\circ} \mathrm{C}$ than at $16^{\circ} \mathrm{C}$. However, two phases can be considered in the response to hypoxia: a highly regulated segment (above $\mathrm{P}_{\mathrm{c}} \mathrm{O}_{2}$ ) and a poorly regulated segment (below $\mathrm{P}_{\mathrm{c}} \mathrm{O}_{2}$ ). The slopes of the highly regulated segments seems as a pertinent criteria to assess oxyregulation ability. This study showed close $\mathrm{P}_{\mathrm{c}} \mathrm{O}_{2}$ values (21.4 and 24.4\%) and no significant difference in the slopes of the highly regulated segments between the two temperature conditions. The combination of these two observations indicates that $A$. purpuratus oxyregulation ability is only slightly affected by temperature. This physiological acclimation ability displayed between these two widely remote temperatures may be linked to an adaptive response to a highly variable environment in terms of temperature and oxygen concentration (e.g. ENSO and high frequency events) and may contribute to explain the wide geographical distribution range displayed by this species.

In the poorly regulated segments, the decrease of oxygen uptake is more abrupt at $25^{\circ} \mathrm{C}$ than at $16^{\circ} \mathrm{C}$ (Fig. 2). This differ- ence can be explained by the higher metabolic rate observed at $25^{\circ} \mathrm{C}$ (that might include oxyregulation effort), causing a more pronounced energetic decrease when oxygen saturation drops near zero. The inability to maintain the oxygen consumption rate below the $\mathrm{P}_{\mathrm{c}} \mathrm{O}_{2}$ marks the beginning of energetic anaerobic pathways (Grieshaber et al., 1988; Pörtner and Grieshaber, 1993). While many bivalves are adapted to survive periodic hypoxia (Le Moullac et al., 2007), less efficient energy production under anaerobic conditions can affect their energetics. The synthesis of endproducts to be metabolized when normoxic conditions resume can generate oxygen debt (Herreid, 1980). Chronic exposure to severe and prolonged hypoxic conditions, as in the Peruvian coastal waters, might affect the A. purpuratus energy budget by reducing the energy available for the major metabolic functions, thus affecting growth, reproduction and immune response with consequences for culture performances.

\section{Conclusion}

The Peruvian-Chilean coastal marine area presents an environment highly variable in terms of temperature and oxygen saturation. The results of this study highlight $A$. purpuratus ability to efficiently regulate its oxygen uptake in a wide temperature range. The observed low oxygen critical points indicate an important regulation capacity of oxygen uptake at both normal and warm conditions. Although oxyregulation decreases considerably for oxygen saturations lower than the critical point, the oxygen uptake under severe hypoxic conditions is not null. The ability of $A$. purpuratus to deal with oxygen limiting conditions might provide an adaptive advantage to acclimate to environmental conditions along its distribution range. Further studies must focus on the anaerobic metabolic capacity and the effect of hypoxia on the energy balance of this scallop species.

\section{Acknowledgments}

We thank the Instituto del Mar del Peru and especially Carla Aguilar for allowing the use of the IMARPE experimental facilities. We thank "Los Chichos" Diego Herrera and Alex Vega for their active help during the experiments. We thank also the Hatchery of "La Arena" (FONDEPES) for providing the scallops used in this experiment. This work is part of a PhD thesis supported by IRD within the framework of the LMI DISCOH, and LabexMER (ANR-10-LABX-19-01).

Aguirre-Velarde, A., Flye-Sainte-Marie, J., Thouzeau, G., Jean, F., 2014. Impact of low oxygen concentrations on scallop culture in the upwellinginfluenced Bay of Paracas, Peru. Poster presented at the low oxygen environments in marine, estuarine and fresh waters colloquium, Liège.

Alexander, J. E., McMahon, R. F., 2004. Respiratory response to temperature and hypoxia in the zebra mussel Dreissena polymorpha. Comp. Biochem. Physiol. Part A 137 (2), 425-34.

Artigaud, S., Lacroix, C., Pichereau, V., Flye-Sainte-Marie, J., 2014. Respiratory response to combined heat and hypoxia in the marine bivalves Pecten maximus and Mytilus spp. Comp. Biochem. Physiol. Part A 175, 135-140.

Avendaño, M., Cantillánez, M., Le Pennec, M., Thouzeau, G., 2008. Reproductive and larval cycle of the scallop Argopecten purpuratus (Ostreoida: Pectinidae), during El Niño-La Niña events and normal weather conditions in Antofagasta, Chile. Rev. Biol. Trop. 56 (1), 121-32. 
Bayne, B. L., Hawkins, A. J. S., Navarro, E., 1987. Feeding and digestion by the mussel Mytilus edulis L. (Bivalvia : Mollusca) in mixtures of silt and algal cells at low concentrations. J. Exp. Mar. Bio. Ecol. 111, 1-22.

Brokordt, K., Pérez, H., Campos, F., 2013. Environmental Hypoxia Reduces the Escape Response Capacity of Juvenile and Adult Scallops Argopecten purpuratus. J. Shellfish Res. 32 (2), 369-376.

Cabello, R., Tam, J., Jacinto, M. E., 2002. Procesos naturales y antropogénicos asociados al evento de mortalidad de conchas de abanico ocurrido en la bahía de Paracas (Pisco , Peru) en junio del 200. Rev. peru. biol. 9 (2), 49-65.

Cantillánez, M., Thouzeau, G., Avendaño, M., 2007. Improving Argopecten purpuratus culture in northern Chile: Results from the study of larval and post-larval stages in relation to environmental forcing. Aquaculture 272, 423-443.

Dunphy, B. J., Wells, R. M., Jeffs, A. G., 2006. Oxygen consumption and enzyme activity of the subtidal flat oyster (Ostrea chilensis) and intertidal Pacific oyster (Crassostrea gigas): Responses to temperature and starvation. New Zeal. J. Mar. Freshw. Res. 40, 149-158.

Gonzales, I., Paredes, J., Segura, M., Macalupú, J., 2012. Mortandad de concha de abanico frente a Vichayo, Barrancos y Parachique (Sechura), 16 febrero 2012. Tech. rep., Instituto del Mar del Perú, Piura.

Gonzalez, M. L., Perez, M. C., Lopez, D. a., 2002. Breeding cycle of the northern scallop, Argopecten purpuratus (Lamarck, 1819) in southern Chile. Aquac. Res. 33 (11), 847-852.

González-Hunt, R. M., 2010. Auge y crisis : la pesquería de la concha de abanico (Argopecten purpuratus) en la región Pisco-Paracas , costa sur del Perú. Espac. y Desarro. 22, 25-51.

Grieshaber, M. K., Hardewig, I., Kreutzer, U., Pörtner, H. O., 1994. Physiological and metabolic responses to hypoxia in invertebrates. Rev. Physiol. Biochem. Pharmacol. 125, 43-147.

Grieshaber, M. K., Kreutzer, U., Pörtner, H., 1988. Critical $\mathrm{PO}_{2}$ of euryoxic animals. In: Acker, H. (Ed.), Oxygen Sensing in Tissues. Springer, Berlin, pp. 37-48.

Griffiths, C., Griffiths, R., 1987. Bivalvia. In: Pandian, T., Vernberg, F. (Eds.), Animal Energetics, Bivalvia through Reptilia, vol. 2. Academic Press, California, pp. 1-87.

Hand, S., Hardewig, I., 1996. Downregulation of cellular metabolism during environmental stress: mechanisms and implications. Annu. Rev. Physiol 58, 539-563.

Herreid, C. F., 1980. Review hypoxia in invertebrates. Comp. Biochem. Physiol. $67 \mathrm{~A}, 311-320$

Hicks, D. W., McMahon, R. F., 2002. Respiratory responses to temperature and hypoxia in the nonindigenous Brown Mussel, Perna perna (Bivalvia: Mytilidae), from the Gulf of Mexico. J. Exp. Mar. Bio. Ecol. 277, 61-78.

Jansen, J. M., Hummel, H., Bonga, S. W., 2009. The respiratory capacity of marine mussels (Mytilus galloprovincialis) in relation to the high temperature threshold. Comp. Biochem. Physiol. A. Mol. Integr. Physiol. 153 (4), 399-402.

Kooijman, S. A. L. M., 2010. Dynamic Energy Budget theory: Summary of concepts of the third edition.

Le Moullac, G., Quéau, I., Le Souchu, P., Pouvreau, S., Moal, J., René Le Coz, J., François Samain, J., 2007. Metabolic adjustments in the oyster Crassostrea gigas according to oxygen level and temperature. Mar. Biol. Res. 3 (5), 357-366.

Llanso, R. J., 1992. Effects of hypoxia on estuarine benthos: the lower Rappahanno River (Chesapeake Bay), a case study. Estuar. Coast. Shelf Sci. 35, 491-515.

Mangum, C., Winkle, W., 1973. Responses of aquatic invertebrates to declining oxygen conditions. Am. Zool 13, 529-541.

Mcmahon, R. F., Wilson, J. G., 1981. Seasonal respiratory responses to temperature and hypoxia in relation to burrowing depth in three intertidal bivalves. J. therm. Biol 6, 267-277.

Muggeo, V. M. R., 2003. Estimating regression models with unknown breakpoints. Stat. Med. 22, 3055-71.

Muggeo, V. M. R., 2008. segmented: An R package to fit regression models with broken-line relationships. R News, 20-25.

Newell, R. C., 1978. Effects of environmental temperaure and hypoxia on the oxygen consumption of the suspension-feeding gastropod Crepidula fornicata L. Comp. Biochem. Physiol., Part A 59A, 175-182.

Pörtner, H., 2012. Integrating climate-related stressor effects on marine organisms: unifying principles linking molecule to ecosystem-level changes. Mar. Ecol. Prog. Ser. 470, 273-290.
Pörtner, H. O., Grieshaber, M. K., 1993. Critical $\mathrm{PO}_{2}$ (s) in oxyconforming and oxyregulating animals: gas exchange, metabolic rate and the mode of energy production. In: Bicudo, J. (Ed.), Vertebr. gas Transp. cascade Adapt. to Environ. mode life, crc press Edition. Boca Raton FL, USA, pp. 330-257.

PRODUCE - Peru, 2015. Anuario estadístico pesquero y acuícola 2013. Tech. rep., Ministerio de la Producción, Lima-Peru.

URL http://www.produce.gob.pe/index.php/estadisticas/anuarios-estadistico

Prosser, L., 1973. Comparative Animal Physiology, 3rd Edition. Saunders, Philadelphia, PA, USA.

R Development Core Team, 2011. R: A Language and Environment for Statistical Computing. R Foundation for Statistical Computing, Vienna, Austria, ISBN 3-900051-07-0.

URL http: //www.R-project.org/

Savina, M., Pouvreau, S., 2004. A comparative ecophysiological study of two infaunal filter-feeding bivalves: Paphia rhomboides and Glycymeris glycymeris. Aquaculture 239, 289-306.

Sokolova, I. M., Pörtner, H.-O., 2003. Metabolic plasticity and critical temperatures for aerobic scope in a eurythermal marine invertebrate (Littorina saxatilis, Gastropoda: Littorinidae) from different latitudes. J. Exp. Biol. 206, 195-207.

Taylor, a. C., Brand, a. R., 1975. A comparative study of the respiratory responses of the bivalves Arctica islandica (L.) and Mytilus edulis L. to declining oxygen tension. Proc. R. Soc. Lond. B. Biol. Sci. 190 (1101), 443-56.

Thiel, H., 1978. Benthos in upwelling regions. In: Boje, R., Tomczak, M. (Eds.), Upwelling Ecosystems. Springer Berlin Heidelberg, pp. 124-138.

Tran, D., Boudou, A., Massabuau, J.-C., 2000. Mechanism for maintaining oxygen consumption under varying oxygenation levels in the freshwater clam Corbicula fluminea. Can. J. Zool. 78, 2027-2036.

Waite, J., Neufeld, G., 1977. Oxygen consumption by Sphaerium simile. Comp. Biochem. Physiol. A57, 373-375.

Willmer, P., Stone, G., Johnston, I., 2005. Environmental Physiology of Animals, Second Edition. Blackwell Publishing, Oxford, UK.

Wolff, M., 1987. Population dynamics of the peruvian scallop Argopecten purpuratus during the El Niño phenomenon of 1983. Can. J. Fish. Aquat. Sci. 44, 1684-1691.

Wolff, M., 1988. Spawning and recruitment in the Peruvian scallop Argopecten purpuratus. Mar. Ecol. Prog. Ser. 42, 213-217. 